\title{
HISTORY AND DEVELOPMENT OF HAKEN'S SYNERGETICS
}

History of the emergence, establishment and development of Haken's synergetics is thoroughly considered. Synergetics as a quite young view of the world has originated due to the necessity of finding adequate, reasonable, calculated and forecasted by science answers to global challenges that civilizational human development makes. Synergetics is a general theory of self-organization. It formulates the general principles of self-organization, which are true for all levels of matter. A peculiarity of synergetic approach is the transition from research of simple systems to the complex ones, from open to closed ones, from linear to nonlinear ones, from the study of equilibrium and process near the equilibrium to the delocalization and instability, to the investigation of things, which are happening far from equilibrium. The contribution of the science schools and H. Haken to the establishment of synergetics is revealed. This article mentions the perspectives of development of Haken's synergetics, nonlinear dynamics as the methodology of solution to the problems, which the economy and the whole society face. Nonlinear dynamics offers the basic models, new terms and methods, which can or cannot be used in such situation. They can become the framework for building the new nonlinear cognitive paradigm or they can stay the separate discoveries in different disciplines. Synergetics is formed as an interdisciplinary scientific approach, which develops the methods of investigation of open systems' behavior and the complex behavior of their components. The perspectives of the use of synergetics in science research are represented. Some systems in physics, chemistry and biology provide the simplest examples of self-organization. Modern areas of research within the framework of synergetics and nonlinear dynamics are considered. The results formed a strong basis for the further research in the field of economic science regarding synergetics. Synergetics is a powerful mathematical tool to analyze and solve modern nonlinear economic phenomena, which form the synergetic system and can't be described by classic economic-mathematical methods. Synergetics is one of effective approaches to general problems of the description of complexity, characteristic of phenomena of self-organization.

Keywords: self-organization; nonlinear science; system; evolution.

Introduction. The obvious fact nowadays is the limitation of cognitive models, their incompleteness, inadequacy and non-applicability to many problems that need to be solved. Society's world of view is changing, broadening and people need the new opportunities to have impact on their own fate. They solve various problems so they need new methods to address the arising issues.

With regard to representatives of the natural sciences and mathematical modelling, a lot of them have to deal with a wide range of issues, starting with problems of strategic stability of the projects of economic reforms and ending with the specific physical processes or technical constructions. Euphoria about the opportunities of the modern computers, computing experiment gave way to the understanding of the limitation of possibility to get an answer off of their capabilities to ask fundamental questions and to form them so that the computer understands.

Materials and methods. Theoretical justification of this change was represented in the new approaches: economic growth theory, business-cycle theory and synergetic economy theory. Synergetic approach to the research of economic processes causes the development of effective models of economy's way out of crisis, which makes it possible to search for the universal principles of self-organiza- tion and evolution of complex economic systems (formulation of laws of self-defense and evolutionary development) (Osipov, 2001).

New economic theory forms the picture of economic processes on the basis of nonlinear correlations and the loss of equilibrium state. Modern research reveals the development of economic processes based on the processes of selforganization and openness. This approach is based on fundamental works of H. Haken (Haken 1983, 1987, 2004), I. Prigogine (1986, 1989, 1991), W. Zhang (1999), I. Lukinov (2002), M. Moiseev (2003) etc., whose investigations substantiated the main stages and formation of development of the open systems by means of evolutionary change through the bifurcation points, catastrophes and chaos. The investigations showed that complex systems, which include economic systems that have features of self-organization and openness, are the dissipative structures, which are able to reproduce their actions and further way of being on the basis of internal potential, which requires certain conditions to be realized. These conditions can be created naturally or due to the regulatory actions.

The investigators pay attention to the consideration of behavior of the systems in the points, which are far from equilibrium and to the opportunity of the system to be in

Інформація про авторів:

Якімцов Віктор Вікторович, канд. екон. наук, доцент, кафедра економіки підприємсmва. Email: yakimtsov@nltu.edu.ua Цитування за ДСТУ: Yakimtsov V. V. History and development of Haken's synergetics. Науковий вісник НЛТУ України. Серія Економічна. 2018, т. 28, № 9. С. 119-125

Citation APA: Yakimtsov, V. V. (2018). History and development of Haken's synergetics. Scientific Bulletin of UNFU, $28(9), 119-125$. https://doi.org/10.15421/40280923 
transition therefore the system gets some sensitivity to the possible options of development and it chooses the trajectory of the best features.

The results formed the strong basis for the further research in the field of economic science in the area of synergetics, which considers elements of estimation and determination of the components during the formation of economic mechanisms as a holistic concept of transitions between the equilibrium states and holding the sustainable development; search for synergetic potential in the internal structure of economic processes and possibility of its reproduction due to the external outrages; formation of the nature of factors that confront in the economic space therefore the economy gets features of nonlinearity and instability etc.

Results. Our world is a complex system. However, the scientists manage to describe and understand it at the primary level and all that gives at least minimal overview. Why do these quite simple and primitive models work? In our opinion, self-organization can be the answer to this question, which nonlinear science offers us. The knowledge of universe details turned out to be the enormous power.

Nonlinear science, which is considered postnonclassical, rests upon even shakier foundation: upon the results of computer modelling and theoretical analysis of unusual phenomena in physics, chemistry, biology, social sphere. A lot of experiments, new algorithms, fundamental theories more and more often base on the images and methods of nonlinear world. However, not only the pursuit of future power explains the resonance in the culture and public consciousness, which is connected to nonlinear science. In our opinion, new cognitive model is being formed in the nonlinear science.

Modern world becomes more and more complex, it opens wider and wider due to the modern investigations, which go beyond the classic disciplines and study nonlinear complex forms and models, existence of one phenomenon or another. The society needs to think, learn to live according to the principles of complexity of existence of various conditions of development of nature, environment, new ideas, human principles and needs, perspectives of human interaction with universe and with one another (internal communications, relationships etc.).

This approach provides positive changes in all aspects of human life and the change of thinking as a process of human's and society's attitude to the environment. First of all, the problems need to be solved in the dynamics, which isn't new in the research theory. Such dynamic approach requires the consideration of time factor in nonlinear models, which in its turn makes them more correspondent, real and fair.

I.e. forecasting future becomes possible and necessary for a certain period of time. This projection is called "the upfront reflection" in science. On the basis of these considerations, the science considers it necessary to investigate exactly the nonlinear world in time and space, because it's exactly this world that contains specific model, which will give the opportunity to create a range of modern structure for itself. The connection to space and time becomes possible due to these nonlinear models. I.e. the opportunities of modern condition of one phenomenon or another, which are linked to the time factor, are predictable opportunities for this phenomenon development.

This gives the opportunity to use laws of human development in a new way - with the prospect of construction and modelling of the future. Way to this future for complex nonlinear systems isn't the one and the search for the right solution and path is investigators' special and prospective task.

Intensive development of nonlinear methods of the research of complex systems and discoveries, which were made in the process of this development, led to the fact that the scientists of different fields concluded about the necessity of generalization of the new knowledge in various areas of scientific research and of synthesis of the new knowledge. That's how the science, which H. Haken (Haken 1983, 1987, 2004) called "Synergetics", appeared. This is the science about interaction.

Synergetics (from the Greek - synergeia) - cooperation, assistance, participation - interdisciplinary field of scientific research, which includes general regularities of processes of the transition from chaos to order and backwards in the open nonlinear systems. H. Haken (Haken, 1983, 1987, 2004) introduced the term "synergetics" in 1969.

Hermann Haken (born July 12 of 1927) - outstanding scientist, who is famous as a founder of term "synergetics" and synergetic approach to the science, interdisciplinary research. Main goal of his investigations is to develop and formulate the ideas of synergetics, which would allow to understand various organized structures and phenomena including the ones of nonlinear nature.

As a theoretical physicist by specialty, he knows mathematics, philosophy, which he studied in universities of Halle (1946-1948) and Erlangen (1948-1950). He was a professor of theoretical physics in Stuttgart University after he got a degree of $\mathrm{PhD}$ in philosophy and natural studies. Later he founded and led the Center of synergetics there - one of the most famous and significant institutions of the problems of synergetic approach to the study of problems and ways of human development. He also investigated the complex systems in the Center in the Florida University, he has more than 100 scientific works about synergetic problems, quantum theory of solid body, studies about the interaction etc.

However, the author of term synergetics is Richard Buckminster Fuller - famous architect and inventor from USA. He offered an approach to the nature as to the vector force system, which was polished during millions of years of evolution, so all its features (durability, power, gravity, temperature etc.) created a sustainable system, structure. He offered this approach in his book "Synergetics: Explorations In The Geometry Of Thinking", which was published in 1974. Fuller assumed that the basis of these elements is the stable tetrahedral lattices, because the nature uses hard and stable forms in its constructions, which can quickly reform (triangle and tetrahedral forms) (Ferkiss \& Fuller \& Applewhite, 1976). Human uses cubic and square constructions, which aren't as stable.

So, Fuller offered the new vector geometry, which he called synergetics and later energetic-synergetic geometry (Ferkiss \& Fuller \& Applewhite, 1976). On the basis of the offered theory he invented, constructed and patented so called "geodesic dome" in 1951, which was the implementation of ideas of creation of artificial construction that would be similar to the natural one, which gave the opportunities to create such constructions with the best results and least costs.

Synergetics as a scientific field is close to the range of other fields, such as nonlinear dynamics, theory of complex adaptive systems, theory of dissipative structures (Prigogine, 1986, 1991), theory of deterministic chaos or fractal geometry (Mandelbrot, 2010), theory of autopoiesis (Matura- 
na \& Varela, 2001), theory of self-organized criticality (Bak, 1991), Nonstationary Structures and diffusion-induced chaos in nonlinear media (Samarskii, 1981; Kurdyumov, 1983, 2002).

Ilya Prigogine was a director of physics and chemistry department of the university in Brussels and director of the Center for Statistical Mechanics and Thermodynamics at the University of Texas in Austin. He is famous as a physicist and a specialist in chemical thermodynamics. He won the Nobel Prize in Chemistry in 1977 for his contributions to non-equilibrium thermodynamics, particularly the theory of dissipative structures. This is current and promising area of the modern science. These principles were further developed in the theories of complex adaptive systems, theories of dissipative structures etc. This has prompted the development of synergetic principles in the science.

Benoît Mandelbrot was a famous mathematician, an author of theory of deterministic chaos or fractal theory, which gives the opportunity to describe and determine a level of complexity of phenomena, objects etc., which is very different from the one that was determined by classic geometry. Fractal by definition of B. Mandelbrot (in Latin - separated, shattered) - irregular and self-similar structure (Mandelbrot 2010). In a broad sense, fractal means a figure, small parts of which are similar to it if arbitrarily increasing.

Synergetics is used as a generalized name of scientific directions that study the processes of self-organization and evolution, ordered behavior of complex nonlinear systems. Synergetics is formed as an interdisciplinary scientific approach, which develops the methods of investigation of open systems' behavior and the complex behavior of their components. Synergetics is one of effective approaches to general problems of the description of complexity, characteristic of phenomena of self-organization. Some systems in physics, chemistry and biology provide the simplest examples of self-organization. The events are moving not only in time, but also in space. They all share one characteristic.

Let's assume the classic example of synergetics. Imagine a diffusion, created by a random walk of multiple particles, imagine the complex trajectories of liquid particles or the multitude of chemical reagents, which turn into one another or a lot of people, who use the urban transport. It all seems accidentally or, as physicians say, there's a chaos at the micro-level. Average values behave in a determined way in all these cases. Chaos at the micro-level can lead to the order at the macro-level. Studying these and some other structures isn't an easy task. It requires the development of new mathematical methods and extensive use of computers, however it's sometimes quite enlightening.

Dealing with the processes, which take place in time and space, we face the new reality element - form of the structure emergence. Thoughts about the perfection of the form, proportionality of harmony were one of the key moments in the nature cognition. It shows what laws can consolidate the simple structures in complex ones: the form determines structure existence. It's necessary to correctly determine the form of the complex structure, which occurs in time, to create it. Amount of energy doesn't matter here.

A wide range of various configurations raised investigators' false illusions about the fact that structures of all complexities can be created in this world. One of the key results of analysis is the proof that we can create only these structures in this environment. However, there are rules of prohibition. Attempts to "impose" something to the system or to work in trial and error are doomed to failure.

A lot of analogies, isn't it? With economic, social and ecological systems, where the attempts to restructure or recreate rarely yield positive outcomes. Our world is far too complex. It includes a lot of conservation laws. The events are moving within the giant interval of spatial scale and timescale. It combines accidents and regularity in an amazing way. Chemistry, physics and biology contain many examples of self-organization, but the mathematical models of these processes are extremely rarely created. Because this is about the understanding and coping with the models of self-organization mechanisms. Many important discoveries in the science of 20th century are linked to the identification of the effect of organizational behavior (synergism) at the macro-level of range of the separate elements (atoms, cells etc.).

How do you explain and model the new formations, economic and natural processes around us? How do you describe their structures, their size, shape or the specter of shapes; their development laws, the laws of their entry into the integrity and breakdown causes? The use of nonlinear mathematical models and the computing experiment gave new opportunities to understand these processes. Unfortunately, the last one is linked to the lack of development of analytical methods of nonlinear models investigation even in the modern mathematics. There are works that illustrate the use of computer modelling of nonlinear processes.

Search for these conceptions, new paradigms, new cognitive models occurs in various ways. One of the approaches is the fundamental change of methodology. Perhaps Hegel's classic black and white triad: "thesis, antithesis, synthesis" gives up to more complex systems during the analysis of complex systems. For example, the ones, which are based on "fuzzy logic" or trinary methodology. R. G. Barantsev takes an active part in developing the last one, which considers the interrelations not between the pairs of categories, but between the triples of them. It's possible to highlight the accuracy, simplicity and universality (scope) during the analysis of method or algorithm. These requirements are contradictory and the third category is often the "arbiter" in the "argument" between the first two categories (Barantsev 2003, 2005, 2006).

Yu. V. Chaikovskii (2003), Yu. Yu. Tunytsya (2002, 2006) and I. M. Sinyakevich (2001) are developing the new approach, they offer the new cognitive model, which is based on ecological imperative and on the change of ethical standards. They are based on the attitude to the world as to the garden that needs harmony.

However, the nonlinear dynamics, synergetics, isn't at this level of synthesis. It so far provides the selected examples, images of behavior of complex nonlinear systems and methods of their investigation. It can be compared to peculiar natural philosophy of the computer era. Myths were at that time giving the examples of typical situations, recommendations of necessary actions if the attempt to rely on logic and rational considerations fails.

Nonlinear dynamics offers the basic models, new terms and methods, which can or cannot be used in such situation (Yakimtsov, 2018). They can become the framework for building the new nonlinear cognitive paradigm or they can stay the separate discoveries in different disciplines.

One of the causes of resonance, which nonlinear dynamics made, lies in the fact that it provides the new view of 
the science development and of the possibility to describe the natural phenomena. Fundamental question is why do we so nicely orient in many things and why did we get to the bottom of a lot of things during past 20 centuries? Cause we don't have plenty of opportunities. How can we identify the most important processes and key factors among the variety of complex interacting factors and hundreds of thousands of variables? Nonlinear dynamics is that the self-organization occurs, it's linked to the separation of the order parameters. Nonlinear environment, which potentially has the infinite degrees of freedom, can be described by the dynamic system with limited or small number of variables. The market with hundreds of thousands agents and millions of goods can be modelled due to the demand and supply curves. (View of the economy as of system, which self-organizes and self-develops, is quite fruitful, as A. A. Petrov's scientific school's works show $(1996,2003))$.

Despite the endogenous scientific nature of the problem of separation of the order parameters, it is extremely important. Approaches, which evolve by nonlinear dynamics, give hope that it's possible to successfully act in the ocean of already available knowledge, projects and that the informational djinn can be tamed. Biblical wisdom gives an interpretation about "the time to scatter the stones" and "time to gather the stones". If XX century was under the sign of "scattering the stones", emergence of hundreds of scientific fields at the interface of scientific disciplines, then in XXI century the future of science will be determined by the extent of successfulness of interdisciplinary synthesis and of the "stones gathering".

Nonlinear science provides good chances for this. Chances of the fact that the huge potential, accumulated by mathematics and natural sciences, turns out to be demanded and useful while answering the key questions, which concern our life. It gives chances to human sciences that we will finally learn the history lessons and be smart where it's most needed. It's nowadays hard to define the outlines of nonlinear paradigm or nonlinear cognitive model. It sometimes seems like a giant vortex that absorbs the assignment, methods and ideas of many different disciplines and it takes the new models and overviews to the new level. However, it's difficult to distinguish the new thing from well overlooked old.

We finally can create a new philosophical and methodological conception with consideration of experience of great scientific and technological projects and interpretation of historical path of human development. M. M. Moiseev consistently and deeply develops this approach as a part of approach called "universal evolutionism" (Moiseev, 2003).

The invention of computing machines, development of modern computer technologies significantly affected the investigations in the economy and changed not only the methodological approaches of economic developments, but also the principal approaches to the research of economic processes along with the other processes - social, technical, natural. Because all of them (processes) have an active impact on one another and they provide a total effect, which significantly differs from what each of these processes would be like separately. Thus, this total effect has to become the basis for scientists' conclusions about the further human development. Synergetics can be the methodological basis of modelling and investigation of economic processes as the complex nonlinear systems.
The ideas of new science, which was later called "synergetics", were for the first time formulated in a science fiction short story of a famous science fiction writer Ray Bradbury "A Sound of Thunder" in 1963 however paradoxical it may be. This story tells about one of organizers of election campaign travelling in time after his candidate's winning. Company, which organizes this trip, offers a dinosaur hunt. The dinosaurs that would have died in the near future. It's necessary to follow special path not to damage the complex system of causality and not to change the future. However, the character couldn't manage and he accidentally crushed a butterfly. He went back and saw that atmospheric composition, spelling rules and the outcome of election campaign changed. A barely noticeable motion toppled the small dominoes, they toppled the bigger dominoes, and the fall of giant dominoes led to the catastrophe. Small creature - a butterfly - managed to cause the big consequences. Disturbing the equilibrium (insignificantly, in very small values) in one place leads to the big chaos - dynamic chaos. Mathematicians called these features of event "A butterfly effect" - sensitivity to a raw data. Chaos theory, which based on this principle-effect, implies that a flap of the butterfly's wing on one side of the world can set off a hurricane on another (Bradbury, 1999).

Meteorologist E. Lorenz offered a model of air convection in 1963, that he described by a system of differential equations, which he calculated several times and couldn't get the identical values. Originally, he used them in six-figure order and then he increased it. The phenomenon on dynamic chaos was formulated this way, the end of result of which was the determination of ending horizon of the projection (Lorenz, 1981). Edward Lorenz - meteorologist from Massachusetts Institute of Technology - calculated the unusual system, which describes the atmospheric phenomena, due to the mathematical equation. When he graphically illustrated this in spatial coordinates, he got a strange object, which he called "strange attractor" (Lorenz, 1981).

This illustration looking like an owl mask or the butterfly wings became a logo of first researchers of the dynamic chaos. It reveals a fine structure in disorder flow of information. Change of values of any variable can be graphically showed depending on time. It's necessary to assume that three variables capture a point in three-dimensional space in order to demonstrate the variable relation among three variables; movement of point circumscribes a continuous line with the system change. Since the system condition is never repeated, the trajectory doesn't cut itself, creating new loops. The motion in the attractor is abstract, nevertheless, it represents the features of the movement of the real systems. For example, the transition from one attractor "wing" to another conforms to the beginning of the back stroke of water wheel or change of direction of rotation of the liquor during the convection.

Meaning of the name "strange attractor" lies in the fact that system (phenomenon) on the one hand obeys the strict laws (of dynamics, development etc.), which have to maintain the system balance - instead of moving forward this equilibrium state, the system behavior is chaotic and it can't be predicted. System components approximately approach the equilibrium state, however, their behavior never can be predicted - how and when this equilibrium state will be achieved. Such systems that are aimed at moving forward the 
equilibrium state are called self-organized, nonequilibrium ones.

These systems-structures are everywhere and that was known in $70 \mathrm{~s}$ of XX century. R. Feynman, who won the Nobel Prize, published his research about the limitations to predict any phenomena, even those that are perfectly described by classic mathematics. Because every small inaccuracy, which exponentially increases and unpredictably guides the phenomenon development, influences on the outcome. That's characteristic behavior for economic processes of human development and technologies.

Dynamic chaos, which was revealed in the systems of any nature, is inherent in economic phenomena and processes so it should be considered during the investigation of economic systems, structures, phenomena etc. Doctor Haken came up with the name of new science - "synergetics" (from the Greek - working together) at the same time. He published his first work in this field "Cooperative phenomena in systems far from thermal equilibrium and in nonphysical systems" (Haken, 1983, 1987, 2004) in 1973.

Synergetics was defined as the interdisciplinary science, which studies open systems with the nonlinear behavior, which are far from equilibrium and are capable of "pseudochaotic dynamics" and of self-determined creation of complex structures. Last ability was called the self-organization. Synergetics uses overviews about the stable imbalanced structures instead of overviews about the equilibrium points, which is inherent in classic science. Synergetics studies the combined effect of many subsystems (mainly similar ones), which results in the creation of new structure (phenomenon) and its functioning of new quality and level. This creation occurs at macroscopic level.

On the other hand, the cooperation of various disciplines and fields of expertise is needed to see the general principles, which guide the self-organized systems. Synergetics is relatively new synthesizing science that studies the laws of self-organization of complex systems. This science includes such fields of expertise as nonlinear dynamics, chaos theory, fractals, catastrophe theory, bifurcations, waves, field effects etc.

Main mathematical research methods in synergetics are: theory of dynamic systems, which is based on qualitative theory of differential equations. Modern research areas within the framework of synergetics and nonlinear dynamics are:

- methods based on statistical physics, which describe the significantly unstable processes;

- thermodynamics of open systems, which studies conditions that preserve stability in a certain environmental range and studies the self-organization conditions;

- the emergence of ordered structures from the disordered ones;

- research of qualitative behavior of solutions of differential equations, which determine the states far from equilibrium depending on change of input parameters. This research area was called the catastrophe theory.

This science's popularity is derived from the fact that it's becoming the language of interdisciplinary communication, which can be understood by physicists, chemists, psychologists, sociologists, economists despite the fact that everybody understands synergetic models in his own way.

Systems, structures and phenomena, which willfully emerge, are called the dissipative "structures". I. R. Prigogine $(1985,1986,2000)$ offered this term, when he studied the dissipativity of phenomena, systems and structures. Dissipativity is a special dynamic condition of open unstable systems, which actively interact with the external environment, can get the special features due to many micro-processes in them. In the end, there will be an integral result at the macro-level. Result in these systems shockingly differs from the results that can be in each separate element of the system. New types of structures can suddenly emerge and the transitions from chaos to order can take place due to the dissipativity in unstable systems.

Self-organized systems are quite complex systems, which have a big number of degrees of freedom, parameters, characteristics etc. However, they don't similarly affect the system result. New features appear in the process of self-organization, they have a bigger impact on the result. This is happening due to the system instability. So the determination of parameters and their values (order) is crucial while modelling such systems. This is main task of synergetic research.

Systems that exist in nature significantly differ from the ones, which are created by human. First ones, as a rule, are stable and capable of self-improvement. The second ones are extremely sensitive to errors, to variation of external factors and they cannot improve themselves unless the human influences.

Issue of system improvement is the main one in synergetics. Optimization of orderliness and organization is especially necessary during the research of global problems energetic, ecological, social and economic. Human should clearly define the internal qualities of the system, its development laws etc. The main idea of synergetics is the idea of principal possibility of the emergence of order and organization of some phenomenon of chaos in the process of self-organization.

Important self-organization factor is the origin of connection between the system and its environment. And the system should be self-organized in this environment to confront the destruction. Such phenomena also exist in nature. Human's task when creating the self-organized systems is to reconcile them with the nature and environment. Improvement of self-organized systems is a complex process and it sometimes determined by seemingly unimportant, insignificant, random factors. But giving their interaction, there is a very different process - those factors that seemed insignificant influence on the general result of the system development in such unexpected way that the system itself has a different meaning and importance.

The system isn't being simply organized, but it's happening anyway. The process of self-organization includes not only the opportune moments and influencing factors, but also the turning points, which will have both positive and negative consequences. Such moments are called the moments (points, positions) of bifurcation - values of system parameters, when the stability of stationary state of the system breaks. They become unstable in relation to the system fluctuation. Fluctuation is a microscopic change in the system, which doesn't lead to the macroscopic change in the state that is close to equilibrium, it also influences on the system evolution in case of its entering the bifurcation points.

Significant fluctuations ${ }^{2}$ can be seen in the immediate area of the bifurcation points, the meaning of random factor is increased etc. The process of self-organization is unpredictable during these moments. It's unknown whether the system will become ordered or it'll become chaotic and unpredictable. The revolutionary change of the system will 
become possible in that case, it will provide the system with another quality and essence.

The scientists more and more often deal with phenomena, where more intensive impact leads to the qualitatively new system behavior. It's needed to use other methods to solve this, namely the nonlinear mathematical models. Analysis of such models is necessary in solving many tasks, especially in sociology, psychology, ecology and economics etc. It's exactly this analysis, which is the main one in synergetics. Taking into account that synergetics is the interdisciplinary science that is based on integration and result of many fields of expertise, it's obvious that synergetic approach is necessary in economics - science about the human development in society and especially in the production process.

There are several definitions of synergetics as a science about self-organization. Famous scientist I. Prigogine $(1986,1990)$, who is one of the founders of synergetic investigations, thought that this science was "a theory of dissipative structures" and this science is called " the theory of dynamic chaos" in USA (Feigenbaum, 1983). This is called autopoiesis theory (self-creation, self-reproduction of living creatures) in Latin America (H. R. Maturana), this is getting more and more popular and used in domestic and foreign literature.

Ambiguity of terms and definitions isn't a random occurrence. Because synergetics is a young science, thoughtful and comprehensive. It needs philosophical inquiry and knowledge of modern mathematics, physics, biology, cybernetics, science about the humans, society, knowledge about the technology of production of modern benefits for people etc. A new impetus was given to synergetics in $80 \mathrm{~s}$ of the last century due to the discovery of opportunities and methods of transition from the order to chaos and vice versa. Outstanding scientist D. Ruelle (Ruelle, 1991) noted that studying chaos as a phenomenon was needed in all fields of experience.

Scientists in all fields of experience say that modern ideas of solving tasks of the modern science already had their philosophical and sometimes practical embodiment of scientists, who lived many centuries ago. Ancient philosophical directions in the East, Asia and Tibet have an extensive chaos theory, self-organization theory etc. So there's a fair question about the correctness and necessity of comprehensive development of such theories using the modern mathematical and physical, computing methods of research. This gives an opportunity to conclude about the commonality of society's overview of the solving many problems. The thought about the commonality of the origin of synergetics ideas, which took place a millennium ago and nowadays.

Discussion and Conclusions. First reason why synergetics, which is based on the modern science's achievements, makes the conclusions on the basis of ancestral knowledge, is a commonality of subject matter of analysis. They study complex self-organized systems and internal features of the system as a self-development source.

Second reason is a new opinion about the problems of wholes and parts. Philosophers of Ancient Greece thought that a part from the whole was much simpler than the whole, so if its characteristics are learnt, then it's possible to learn the characteristics of the whole.

However, the researchers later concluded that the object (process, phenomenon etc.) got new features, which weren't similar to those, which the part of these processes had. So there's a necessity of new scientific approaches of learning the whole considering its each part's influence on it.

Third reason of emergence of synergetics is a necessity of development of this strategy of investigation of the complex systems (which are used to describe the phenomena, processes), which would reconcile the methods of studying the simple systems according to the laws of nature with the methods of studying the complex systems and the possibility and necessity to forecast and predict the development of phenomena, events and their results.

Possibility of modelling and calculating mathematically complex systems is linked to the processes of development of the computing equipment and computer technologies. The horizons of predictions are broadened due to these new achievements and they provide the investigator with the opportunity to get the desired results in necessary horizons, lags and sometimes a quite distant future.

\section{Перелік використаних джерел}

Akhromeeva, T. S., Kurdyumov, S. P., Malinetsky, G. G., \& Samarskii, A. A. (1992). Non-Stationary Structures and Diffusion Chaos. Moscow: Nauka, 542 p. [In Russian].

Bak, P., \& Chen, K. (1991). Self-Organized Criticality. Scientific American, 264(1), 46-53. https://doi.org/10.1038/scientificamerican0191-46

Barantsev, R. G. (2003). Synergetics in the modern science: Documents, conersations, comments, $144 \mathrm{p}$.

Barantsev, R. G. (2005). Establishment of trinary thinking: Documents, conersations, comments, $124 \mathrm{p}$.

Barantsev, R. G. (2006). History of semiodynamics: Documents, conersations, comments, $380 \mathrm{p}$.

Bradbury, Ray. (1999). The golden apples of the sun. Published 1999 by Earthlight in London. 168 p.

Chaikovskii, Yu. V. (2003). Evolution. Coenological Studies. Moscow: Center of systemic studies, $472 \mathrm{p}$. [In Russian].

Chance, R. D., \& Ruelle, C. D. (1991). Princeton University Press, $214 \mathrm{r}$.

Feigenbaum, M. J. (1983). Universal behavior in nonlinear systems. Physica D: Nonlinear Phenomena, 7(1-3), 16-39. https://doi.org/10.1016/0167-2789(83)90112-4

Ferkiss, V., Fuller, R. B., \& Applewhite, E. J. (1976). Synergetics: Explorations in the Geometry of Thinking. Technology and Culture, 17(1), 104-107. https://doi.org/10.2307/3103256

Haken, H. (1983). Synergetics: An Introduction, Springer Ser. Synergetics, (Vol. 1, 3rd ed.), printing (Springer, Berlin, Heidelberg https://doi.org/10.1007/978-3-642-45553-7 1

Haken, H. (1987). Advanced Synergetics: Springer Ser. Synergetics, (Vol. 20, 2nd ed.), printing (Springer, Berlin, Heidelberg). https://doi.org/10.1007/978-3-642-45553-7

Haken, H. (2004). Synergetics: Introduction and Advanced Topics, (Vol. 1, 3rd ed.), printing (Springer, Berlin, Heidelberg) https://doi.org/10.1007/978-3-662-10184-1 2

Kapitsa, S. P., Kurdyumov, B. B., \& Malinetsky, G. G. (1997). Synergetics and Forecasts of the Future. Moscow: Nauka, 285 p. [In Russian].

Kudin, S., \& Mironovich, Yu. (2008). Synergetics of institutional change of economy in Ukraine, (pp. 257-260). Lviv, 360 p. [In Ukrainian].

Kurdyumov, S. P., \& Malinetskii, G. G. (1983). Synergetics - theory of self-organization. Ideas, methods, perspectives. Moscow: Nauka, 280 p. [In Russian].

Kurdyumov, S. P., \& Malinetskii, G. G. (2002). Prologue. Synergetics and system synthesis. Looking to the third millennium. Moscow: Nauka, 420 p. [In Russian].

Kurdyumov, S. P., Malinetskii, G. G., Popov, Yu. P., Poveschenko, Yu. A., \& Samarskii, A. A. (1981). Dissipative structures in trigger media. Differ. Uravn., 17(10), 1875-1886.

Lorenz, E. (1981). Deterministic nonperiodic flow. Strange attractors, (pp. 88-116). Moscow: Nauka, 260 p. [In Russian]. 
Lukinov, I. I. (2002). Evolution of economic systems, (pp. 123-129). Moscow: Publishing House of the "Economy ", 567 p. [In Russian].

Mandelbrot, B. (2002). The Fractal geometry of nature. Moscow: Institute of computer science, 656 p. [In Russian].

Maturana, H., \& Varela, F. (2001). The Tree of Knowledge: The Biological Roots of Human Understanding, 224 p.

Moiseev, N. N. (2003). Universum. Information. Society. Moscow: Publishing House of the "Economy", 367 p. [In Russian].

Osipov, Yu. M. (2001). Eschatology of new world. Strange attractors, $6(18), 11-19$

Petrov, A. A. (2003). Ob ekonomike yazikom matematiki, 112 p.

Petrov, A. A., Pospelov, I. G., \& Shananin, A. A. (1996). Experience of mathematical modeling for economy, (pp. 142-147). Moscow: Nauka, 544 p. Retrieved from: https://ru.wikipedia.org/wiki/Shananin,_Aleksandr_Alekseevich

Prigogine, I. (1989). The Rediscovery of Time. Questions of Philosophy, 8, 3-20.

Prigogine, I. (1991). Philosophy instability. Questions of philosophy, $6,46-57$.
Prigogine, I., \& Stengers, I. (1986). Order Out of Chaos: Mans New Dialogue with Nature, $432 \mathrm{p}$.

Prigogine, I., \& Stengers, I. (2000). Time, Chaos, Quantum: Towards the Resolution of the Paradox of Time. Moscow: Publishing House of the "Economy", 240 p. [In Russian].

Sinyakevich, I. M. (2001). Ecological and forest policy. Lviv, 202 p. [In Ukrainian].

Tunitsa, Yu. Yu. (2002). Ecological constitution of Earth. Idea. Conception. Problems. Lviv Publishing center of Lviv national university, $298 \mathrm{p}$.

Tunitsya, Yu. Yu. (2006). Ecological economy and market: overcoming contradictions. Lviv Publishing center of Lviv national university, $314 \mathrm{p}$.

Yakimtsov, V. V. (2018). Analytic overlook of the methodology of synergetics in postnonclassical science. Baltic Journal of Economic Studies, 4(2), 254-260. https://doi.org/10.30525/2256-0742/2018-4-2-254-260

Zhang, Wei-Bin. (1999). Synergetic economics: time and change in nonlinear economics. $366 \mathrm{p}$. https://doi.org/10.1007/978-3-642-75909-3

В. В. Якімцов

Національний лісотехнічний університет Украӥни, м. Львів, Україна

\section{ІСТОРІЯ ТА РОЗВИТОК СИНЕРГЕТИКИ ХАКЕНА}

Грунтовно розглянуто історію виникнення, становлення та розвитку синергетики німецького вченого Германа Хакена. Наведено вклад наукових шкіл у становлення синергетики, а також іiі засновника - Г. Хакена. Подано перспективи розвитку синергетики Хакена, нелінійної динаміки як методології вирішення проблем, що постають перед економікою зокрема та людством загалом. Висвітлено перспективи застосування синергетики у наукових дослідженнях. Розглянуто сучасні напрямки досліджень у рамках синергетики та нелінійної динаміки. Синергетика є одним з ефективних підходів до загальних проблем опису складності, характерної для явищ самоорганізації. За отриманими результатами сформовано потужний базис для подальших досліджень у галузі економічної науки в напрямі синергетики. Синергетика досліджує якості цілого не як прямий підсумок його окремих складових частин, а як результат, що має свої, інакші якості. Такий підхід є надсучасним у дослідженнях процесів-явищ і потребує цілісного, системного аналізу багатьох об'єктів із використанням актуальних технологій та методів досліджень. Треба зауважити, що успіх у такому системному підході дослідження надскладних систем, явищ та процесів (наприклад екологічних систем) може бути лише за умов знання внутрішніх характеристик системи та всебічного вивчення законів природи та постійних змін в ії розвитку. Отже, на нашу думку, синергетика - це новітній підхід, на кшталт, програми теоретичного дослідження процесів самоорганізації явищ, процесів тощо, зокрема і проблем розвитку суспільства як в історичному, так і в технолого-економічному напрямку.

Ключові слова: самоорганізація; нелінійна наука; система; еволюція синергетики.

В. В. Якимцов

Национальный лесотехнический университет Украины, г. Львов, Украина

\section{ИСТОРИЯ И РАЗВИТИЕ СИНЕРГЕТИКИ ХАКЕНА}

Рассмотрена история возникновения, создания и развития синергетики немецкого учена Германа Хакена. Представлен вклад научных школ и Г. Хакена в становлении синергетики. Описаны перспективы развития синергетики Хакена и нелинейная динамика как методология решения проблем, с которыми сталкивается экономика и социум. Они могут стать основой для построения новой нелинейной когнитивной парадигмы или они могут оставаться отдельными открытиями по разным дисциплинам. Синергетика формируется как междисциплинарный научный подход, в котором разрабатываются методы исследования поведения открытых систем и сложного поведения их компонентов. Представлены перспективы использования синергетики в научных исследованиях. Рассмотрены современные области исследований в рамках синергетики и нелинейной динамики. Результаты стали прочной основой для дальнейших исследований в области экономической науки на основе синергетики. Синергетика - один из эффективных подходов к общим методам описания проблем, характерных для явлений самоорганизации. Синергетика исследует качества целого не как прямой результат его отдельных составляющих, а как результат, который имеет свои, уникальные качества. Такой подход актуален, сверхсовременен в исследованиях процессов-явлений и требует целостного, системного анализа многих объектов с использованием актуальных технологий и методов исследований. Следует заметить, что успех в таком системном подходе исследования сверхсложных систем, явлений и процессов (например экологических, социальных систем) может быть лишь при условии знания внутренних характеристик системы и всестороннего изучения законов природы и постоянных изменений в ее развитии. Итак, по нашему мнению, синергетика - это новейший подход, так же как программы теоретического исследования процессов самоорганизации явлений, процессов и т.п., в том числе проблем развития общества как в историческом, так и в технолого-экономическом направлении.

Ключевые слова: самоорганизация; нелинейная наука; система; эволюция синергетики. 